\title{
Impactos do Programa de Ação Econômica do Governo (1964-1967) na Indústria de Transformação
}

\section{Impacts of Government Economic Action Program (1964- 1967) in the Manufacturing Industry}

\author{
Marcelo Álvares de Lima Depieri ${ }^{a}$ \\ Júlio Manuel Pires ${ }^{\mathrm{b}, \mathrm{c}}$
}

\begin{abstract}
Resumo: Entre 1964 e 1967, durante o primeiro governo militar, implementou-se o Programa de Ação Econômica do Governo (Paeg), cujos objetivos principais compreendiam o combate às elevadas taxas de inflação e à crise do balanço de pagamentos. A despeito dessas prioridades precípuas, havia também, por parte das autoridades econômicas, a preocupação com o crescimento econômico. A meta de crescimento de $6 \%$ ao ano não foi atingida, o Brasil cresceu 4,2\% em média no período. Tal média, no entanto, como toda média, oculta a diversidade de desempenhos entre os diversos setores. Entre os setores mais atingidos pelas políticas restritivas adotadas nesse interregno, destaca-se a indústria de transformação, cujo desempenho foi o menos empolgante e o mais errático. O objetivo do presente artigo é examinar os efeitos da política fiscal, monetária e creditícia do Paeg sobre o desempenho geral da economia brasileira e, mais especificamente sobre a indústria de transformação e seus principais setores.
\end{abstract}

Palavras-chave: Paeg. Economia brasileira. Política monetária e creditícia. Estabilização econômica.

Abstract: Between 1964 and 1967, during the first military government, the Government Economic Action Program (Paeg) was implemented, whose main objectives were combating high inflation rates and the balance of payments crisis. Despite these priorities, there was also, by the part of the economic authorities, the concern with economic growth. The growth target of $6 \%$ per year was not achieved, Brazil grew by $4,2 \%$ on average in the period. Such average, however, like all average, hides the diversity of performance across various sectors. Among the sectors most affected by the restrictive policies adopted in this interregnum stands out the manufacturing industry, whose performance was the least exciting and the most erratic. The objective of this article is to examine the effects of Paeg's fiscal, monetary and credit policy on the general performance of the Brazilian economy, and more specifically on the manufacturing industry and its main sectors.

a Universidade Paulista (UNIP), Instituto de Ciências Sociais e Comunicação (ICSC), Ciências Econômicas. São Paulo, São Paulo, Brasil.

b Pontifícia Universidade Católica de São Paulo (PUC-SP), Faculdade de Economia, Administração e Contabilidade (FEA), Departamento de Economia. São Paulo, São Paulo, Brasil.

c Universidade de São Paulo (USP), Faculdade de Economia Administração e Contabilidade de Ribeirão Preto (FEA-RP/USP), Departamento de Economia. Ribeirão Preto, São Paulo, Brasil. 
Keywords: Paeg. Brazilian economy. Monetary and credit policy. Economic stabilization.

JEL Classification: N16; O2; O23; O25.

\section{Introdução}

Os primeiros anos da década de 1960 caracterizaram-se por uma grande instabilidade econômica, social e política. Houve a renúncia de Jânio Quadros, menos de sete meses após sua posse, o conturbado período parlamentarista, no qual se sucederam três gabinetes, encerrando-se com o plebiscito, em janeiro de 1963, e o ainda mais conturbado governo João Goulart, o qual não chegou a completar nem a metade do mandato de três anos que ainda lhe restava antes de ser deposto por um golpe militar.

Foi um momento de forte acirramento das divergências políticas e de polarização da sociedade, cujos símbolos máximos foram o Comício da Central do Brasil, em 13 de março de 1964, seguido, nas semanas posteriores, pelas Marchas da Família com Deus pela Liberdade em diversas cidades do país. O golpe militar, encetado em 31 de março, estabelece uma ditadura, cujas perspectivas de limitada duração são substituídas por mais de duas décadas de governo autoritário.

No campo econômico, duas prioridades se impõem nesse momento: as políticas de estabilização (combate à inflação e à crise no balanço de pagamentos) e a realização das reformas institucionais, dois problemas enfrentados de forma muito exígua no período final do populismo, conquanto já se apresentassem como emergenciais.

Uma vez alçados ao poder, os militares - à frente o Marechal Humberto de Alencar Castello Branco e sua equipe econômica -, tinham a missão precípua de elaborar e colocar em prática um programa de estabilidade econômica, paralelamente à realização das reformas tributária, financeira e do mercado de capitais, bem como atacar o problema do estrangulamento externo. Essas medidas foram sintetizadas no Programa de Ação Econômica do Governo (Paeg), lançado no final de 1964.

No que tange ao objetivo de alcançar a estabilidade de preços - a meta era chegar a 10\% de inflação a partir de 1966 -, o Paeg se propôs a utilizar três conjuntos de medidas: uma política fiscal mais restritiva, a implantação de uma política salarial mais austera e um controle mais estrito sobre a expansão monetária e creditícia.

Em relação à política salarial executada no interregno do Paeg, não há qualquer dúvida quanto ao seu caráter restritivo. No entanto, quando se examina o uso efetivo que se fez da política fiscal, monetária e creditícia no combate inflacionário, restam dúvidas e controvérsias importantes. A forma errática como foi tratada a política monetária do período, ora com apertos monetários e creditícios, 
ora com expansão da moeda e do crédito, reflete uma das grandes preocupações dos formuladores do Paeg: estabilizar a economia, mas sem se descuidar do crescimento econômico. No que tange à política fiscal, conquanto tenha ocorrido uma inequívoca redução do déficit público no período 1964-1967, há que se considerar até que ponto a elevação do aporte de recursos aos bancos públicos - sobretudo o Banco Nacional de Desenvolvimento Econômico (BNDE) - não atenuou seu caráter restritivo.

Em que pese a vasta literatura disponível sobre esse período-chave de nossa história econômica recente, acredita-se haver uma lacuna importante a ser preenchida relativamente ao Paeg. Trata-se de examinar o impacto desse programa de estabilização sobre o nível de atividade econômica e especialmente sobre o setor industrial e seus principais subsetores, os quais foram os mais afetados pelas medidas econômicas governamentais do período. $\mathrm{Na}$ análise dos dados referentes ao comportamento da produção dos setores da indústria de transformação, foram utilizados periódicos e revistas econômicas da época, como a Revista Conjuntura Econômica e o Anuário Estatístico, materiais pouco explorados pela literatura relativa ao Paeg.

Nesse sentido, o objetivo deste artigo é examinar os efeitos da política anti-inflacionária, com destaque para as políticas monetária e creditícia, no período 1964-1967, sobre a indústria de transformação no Brasil, ressaltando o impacto nos principais subsetores industriais.

Para tanto, o texto estrutura-se mais em quatro seções, além desta introdução: a segunda discute uma das características básicas do programa gradualista de combate à inflação levado adiante entre 1964 e 1967, ressaltando o papel da política salarial; a terceira destaca as medidas tomadas no âmbito monetário/creditício e seus impactos na indústria de transformação no Brasil; a quarta examina de modo pormenorizado os efeitos sobre os principais subsetores industriais; e, por fim, a quinta encerra o trabalho com as considerações finais.

\section{Resolvendo o Problema: o Paeg e a Política de Estabilização}

No início dos anos de 1960, o Brasil passava por um ambiente de grande instabilidade política. Durante todo o período democrático, 1945-1964, poucos foram os presidentes que conseguiram terminar o seu mandato de acordo com as regras constitucionais. ${ }^{1}$ Na primeira metade dos anos 1960 , essa instabilidade potencializou-se. $\mathrm{O}$ embate entre as forças políticas estava acalorado, as demandas

1 Nesse período, além do governo de Eurico Gaspar Dutra, houve o segundo governo de Getúlio Vargas, que terminou com seu suicídio; Juscelino, apesar de cumprir os cinco anos de mandato, deparou-se com sérias dificuldades que ameaçaram sua posse e uma tentativa de golpe posteriormente; Jânio Quadros renunciou; e João Goulart foi deposto pelos militares. 
por reformas, ${ }^{2}$ provenientes de diversos segmentos da sociedade, eram uma realidade candente da sociedade brasileira. As mudanças ou tentativas de mudanças no campo econômico e político eram inevitáveis. O que estava em jogo era quais seriam essas reformas, de que forma seriam feitas e a que custo.

Aos problemas políticos se juntavam as adversidades na área econômica. A economia brasileira vinha acumulando problemas que se tornaram obstáculos determinantes para o seu próprio desenvolvimento. Entre os anos de 1961 e 1964, a economia brasileira havia reduzido fortemente sua capacidade de importação, instrumento essencial para a continuidade do processo de substituição de importações, apresentando períodos de estagnação, como o crescimento de apenas 0,6\% no ano de 1963 e a intensificação do processo inflacionário, alcançando taxa anualizada próxima a 100\% no primeiro trimestre de 1964.

A disputa política foi resolvida por meio de um instrumento violento. A disputa na arena econômica, por sua vez, se utilizou da força política para ser dirimida. A partir do golpe civil-militar, iniciado em 31 de março de 1964, instalou-se uma ditadura militar no país que duraria mais de 20 anos.

É no contexto autoritário que o Paeg é elaborado e colocado em prática. O lançamento oficial do programa foi realizado no governo Castello Branco, em novembro de 1964. O então presidente escolheu dois economistas bastante conhecidos nos meios políticos e acadêmicos para as pastas da Fazenda e do Planejamento: Roberto de Oliveira Campos assumiu o Ministério do Planejamento e na pasta da Fazenda o nomeado foi Octávio Gouvêa de Bulhões.

Bulhões ${ }^{3}$ era um dos principais representantes do pensamento econômico liberal brasileiro desde os anos 1940, porém “[...] tinha uma linguagem liberal menos radical que Gudin, mostrando-se, por exemplo, mais tolerante a iniciativas de planejamento parcial [...]" (BIELSCHOWSKY, 1996, p. 39).

Já Campos era um diplomata que se graduou no curso de Economia pela Universidade de Columbia. Obteve destaque nacional na década de 1950 defendendo um desenvolvimento econômico industrial com participação do Estado e auxílio do capital estrangeiro.

Campos representa, no panorama político brasileiro do nosso período, a "ala direita" da posição desenvolvimentista. Trabalhou no projeto de industrialização do país e bateu-se pelo planejamento do desenvolvimento econômico. Ao mesmo tempo, defendeu a atração de capitais estrangeiros, inclusive para mineração e energia, e atacou a solução estatal para investimentos em quase todos os casos em que vislumbrava uma solução privada (BIELSCHOWSKY, 1996, p. 39).

$2 \quad$ Para mais detalhes sobre o debate acerca das reformas na década de 1960, ver Figueiredo (1993).

3 "Bulhões foi o criador da Superintendência da Moeda e do Crédito (Sumoc), em 1945, e um incansável instigador da criação do Banco Central” (BIELSCHOWSKY, 1996, p. 40). 
Tendo em vista o currículo e suas posições econômicas, os objetivos da política econômica do período seriam voltados para a estabilização, tendo seu maior foco no combate inflacionário. Além do combate inflacionário, o Paeg possuía outros objetivos. A seguir são listados todos os objetivos do Paeg, de acordo com o que consta no documento oficial do programa:

a) acelerar o ritmo de desenvolvimento econômico do país, interrompido no biênio 1962/1963;

b) conter, progressivamente, o processo inflacionário durante 1964 e 1965, objetivando um razoável equilíbrio de preços a partir de 1966;

c) atenuar os desníveis econômicos setoriais e regionais, e as tensões criadas pelos desequilíbrios sociais, mediante a melhoria das condições de vida;

d) assegurar, pela política de investimentos, oportunidades de emprego produtivo à mão de obra que continuamente aflui ao mercado de trabalho;

e) corrigir a tendência a déficits descontrolados do balanço de pagamentos, que ameaçam a continuidade do processo do desenvolvimento econômico, pelo estrangulamento periódico da capacidade para importar (MINISTÉRIO DO PLANEJAMENTO E COORDENAÇÃO ECONÔMICA, 1964, p. 15).

O diagnóstico dos formuladores do plano era que as causas inflacionárias da economia brasileira se apresentavam em maior grau no lado da demanda: o déficit público, a expansão creditícia às empresas e os aumentos salariais acima do aumento da produtividade. Tomando isso como pressuposto, a política econômica não deveria ser pautada por intentos desenvolvimentistas, mas sim por medidas restritivas visando, sobretudo, a estabilização de preços e o equilíbrio externo.

Martone (1984) problematiza o diagnóstico inflacionário do Paeg chamando atenção para a inflação de oferta, fator que não foi objeto de preocupação central dos formuladores do plano. Para o autor, as tensões de custo associadas, sobretudo, ao aumento da taxa de juros, à política realista de preços públicos e às desvalorizações cambiais tinham um papel importante no processo inflacionário que não foi adequadamente considerado no diagnóstico do Paeg. ${ }^{4}$

No entanto, não se pode afirmar que o Paeg se constituía em um plano ortodoxo de combate à inflação. De acordo com Resende (1989), era um plano que ressaltava a importância de manter certa taxa mínima de crescimento econômico. O combate à inflação deveria ser realizado com a preocupação de que não se constituísse como um entrave para a atividade econômica - a meta proposta no Paeg era de um crescimento médio de $6 \%$ ao ano - e a concepção do plano implicava adotar uma estratégia gradualista para a queda dos índices inflacionários.

4 Havia também, no diagnóstico do Paeg quanto à inflação, algumas concessões aos estruturalistas, mediante a inserção de algumas considerações quanto ao papel das inelasticidades de oferta. No entanto, tais considerações adquiriram caráter totalmente secundário no diagnóstico geral e principalmente na definição das medidas cabíveis. 
É importante, neste momento da exposição, o ponto de vista aqui adotado sobre os determinantes do processo inflacionário no início dos anos 1960 para, a partir daí, ser possível entender melhor as razões do sucesso relativo da política de estabilização do Paeg. Considera-se, como Souza (2001), que não é contraditório associar os determinantes de demanda e de oferta (custos) para se obter uma elucidação mais precisa do processo inflacionário: "Adotar a abordagem da inflação de custos não significa negar a inflação de demanda como uma possibilidade empírica, mas, apenas ampliar o campo de análise, incluindo também a inflação de custos como um resultado teórico plausível [...]" (SOUZA, 2001, p. 26).

No caso específico do Paeg, tal programa se propôs a combater o processo inflacionário ascendente no início dos anos 1960 utilizando um diagnóstico e uma terapêutica mais abrangentes possíveis sobre a inflação, valendo-se tanto de uma perspectiva ortodoxa - identificando as causas da inflação com o déficit público e com a política monetária e creditícia expansionista - quanto heterodoxa - relacionada a custos -, na medida em que os formuladores do plano colocavam a contenção salarial como imprescindível para os objetivos da política de estabilização. No entanto, uma análise mais percuciente do que de fato ocorreu durante o Paeg revela uma exígua consistência com a abordagem de inflação de demanda, denotando uma congruência muito maior com os fundamentos da inflação de custo, sobretudo pela relevância precípua da política salarial consoante a explanação subsequente.

As metas de inflação variavam decrescentemente ano a ano: 80\% em 1964; $25 \%$ em 1965; e 10\% em 1966. Nesse aspecto, o Paeg apresentava muita semelhança com o Plano Trienal, o qual foi elaborado em um governo considerado progressista com João Goulart na presidência e elaborado pelo desenvolvimentista Celso Furtado. O principal ponto de divergência entre o Paeg e o Plano Trienal estava no tratamento efetivo dado à questão salarial.

O plano de Celso Furtado, basicamente, propunha reajustes de $40 \%$ no salário mínimo e para o funcionalismo, já o Paeg apresentava bem definida sua proposta para a política salarial. ${ }^{5}$ No lugar da antiga forma de ajuste salarial, o programa de estabilização de Campos e Bulhões preconizava que o salário fosse reajustado de acordo com a média salarial dos últimos 24 meses, mais a porcentagem do aumento da produtividade e mais um resíduo inflacionário que seria uma previsão da inflação futura. Porém, a inflação prevista pelo Paeg seria menor que a realmente registrada, fazendo com que os salários perdessem poder de compra nesse período, fato admitido até mesmo por um dos destacados elaboradores do Paeg, como o faz Simonsen (1979b, p. 132), ressaltando quem seriam os ganhadores e perdedores do processo de estabilização:

5 "O programa [Paeg] reconhecia que numa inflação crônica os salários reais oscilam fortemente entre picos e vales, devido à conjugação de altas salariais descontínuas com altas contínuas de preços, e que a meta a ser estabelecida deveria ser a estabilização pela média (mais aumentos vegetativos de produtividade) e não pelos picos [...]" (SIMONSEN, 1979a, p. 108). 
Devido à subestimativa do resíduo inflacionário, esse critério parece ter provocado certo declínio dos salários reais entre 1965 e 1967, o que afinal era a contrapartida da melhoria de posição que se pretendia garantir aos locadores de imóveis, aos concessionários de serviços de utilidade pública, aos portadores de títulos de renda, e aos demais beneficiários da inflação corretiva (SIMONSEN, 1979b, p. 132).

É importante ressaltar que a sustentação da política salarial do Paeg se deu em grande parte por conta do contexto autoritário vigente. De um lado, o congresso tinha sobre sua cabeça a lâmina afiada da cassação de mandatos, frequentemente utilizada por Castello Branco e, de outro, os sindicatos dos trabalhadores perdiam força e representatividade. Era prática comum as intervenções do governo e, até mesmo, o fechamento de sindicatos, enfraquecendo o poder de barganha do lado dos trabalhadores.

A diminuição do déficit público era outro fator importante para conter a inflação e foi a política mais bem-sucedida do Paeg, principalmente via o aumento da arrecadação e pela inserção de novos mecanismos de financiamento. Segundo Simonsen (1979a, p. 83), o déficit da União como porcentagem do produto nacional bruto decresceu de 4,2\% para 1,1\% entre 1963 e 1966. A política tributária visava aperfeiçoar o sistema de fiscalização e de arrecadação, inserindo a correção monetária nos atrasados fiscais e modernizando o sistema tributário e o aparato fiscal. Além disso, durante o Paeg, a forma de financiamento do déficit público foi mudando de emissões de papel-moeda para venda de títulos da dívida pública, reduzindo as pressões inflacionárias por esse lado. A correção monetária ${ }^{6}$ ajudou a restauração do prestígio da dívida pública federal. Com a instituição das Obrigações Reajustáveis do Tesouro Nacional (ORTN), revigorou-se a comercialização dos títulos da dívida pública, e o governo usou como instrumento para o financiamento do déficit público uma forma de financiamento não inflacionário. ${ }^{7}$ Todavia, quando se trata do papel do dispêndio público na política anti-inflacionária, há que se sopesar - como já anotado anteriormente, mas que não custa frisar - os incrementos verificados no tocante aos financiamentos operados por agências públicas, como patenteados na seção seguinte.

Atreladas ao objetivo de diminuição do déficit público estavam as mudanças no setor externo. A política cambial seria bem diferente do que em geral ocorreu

6 "A introdução da correção monetária tornava sem sentido a Lei da Usura, eliminando uma série de ineficiências do sistema financeiro. Ao permitir a prática de taxas de juros reais positivas, estimulava a poupança e ampliava a capacidade de financiamento da economia [...]" (VASCONCELLOS; GREMAUD; TONETO JÚNIOR, 1999, p. 247).

7 "De um modo geral o Governo Castello Branco reservou a correção monetária para aquelas áreas em que ela se mostrava mais recomendável do ponto de vista do estímulo à produção, à equidade fiscal e ao mercado de capitais. O campo politicamente mais tentador para a indexação, o dos salários, foi devidamente contornado pela fórmula de reajustamento pela média e não pelo pico [...]" (SIMONSEN, 1979b, p. 131-132). 
nas duas décadas anteriores. O governo Castello Branco, com essa política cambial, objetivava estimular a expansão das exportações com um câmbio que desse incentivo ao setor. "Quanto às importações, a ideia era eliminar os limites quantitativos e utilizar apenas a política tarifária como forma de controle [...]” (VASCONCELLOS; GREMAUD; TONETO JÚNIOR, 1999, p. 250).

\section{A Política Monetária e Creditícia do Paeg e seus Efeitos sobre a Indústria}

Um importante instrumento contido no Paeg para a realização da política de estabilização era o controle da política monetária e creditícia. Para que a expansão monetária não fosse excessiva e não pressionasse os preços, o Paeg previa dois tipos de medidas: a primeira era reduzir os déficits governamentais que obrigavam as autoridades monetárias a emitirem moeda; a segunda era o controle do crédito ao setor privado. Neste caso, havia um dilema a ser enfrentado. Em um contexto de alta nos custos de produção, a restrição de crédito poderia ter um impacto recessivo expressivo. Nesse sentido, o controle monetário previsto pelo Paeg era aceitável até o ponto em que não prejudicasse o crescimento da economia.

A política monetária se mostrou bastante errática durante o período de 1964 a 1967, variando ano a ano. Em 1964, após o golpe militar, a política foi mais flexível do que no ano anterior, apenas no último trimestre do ano é que a variação da liquidez real foi negativa. Além disso, a restrição monetária foi menor do que a redução operada no crédito ao setor privado, como é possível observar na Tabela 1.

Tabela 1 - Brasil: índices de liquidez real, taxas de crescimento real nos últimos 12 meses (\%): * 1964-1967

\begin{tabular}{lcccc}
\hline Anos e trimestres & $\begin{array}{c}\text { Meios de } \\
\text { pagamento }\end{array}$ & $\begin{array}{c}\text { Empréstimos ao } \\
\text { setor privado }\end{array}$ & $\begin{array}{c}\text { Empréstimos de } \\
\text { bancos comerciais ao } \\
\text { setor privado }\end{array}$ \\
\hline 1964 & I & -6 & -14 & -15 \\
& II & 2 & -4 & -1 \\
& III & 0 & 1 & 5 \\
1965 & -7 & -7 & -6 \\
& IV & 9 & 2 & 5 \\
1966 & 17 & 6 & 15 \\
& I & 30 & 12 & 23 \\
& II & 42 & 25 & 41 \\
& III & 21 & 16 & 28 \\
& IV & 1 & 8 & 9 \\
& I & -12 & 1 & -3 \\
\hline
\end{tabular}

Continua... 
Conclusão.

\begin{tabular}{ccccc}
\hline Anos e trimestres & $\begin{array}{c}\text { Meios de } \\
\text { pagamento }\end{array}$ & $\begin{array}{c}\text { Empréstimos ao } \\
\text { setor privado }\end{array}$ & $\begin{array}{c}\text { Empréstimos de } \\
\text { bancos comerciais ao } \\
\text { setor privado }\end{array}$ \\
\hline 1967 & I & -5 & 2 & -4 \\
& II & 10 & 14 & 14 \\
& III & 18 & 10 & 22 \\
& IV & 20 & 26 & 33 \\
\hline
\end{tabular}

Fonte: Resende (1989).

Nota: *Indicadores de liquidez deflacionados pelo IPCA.

No ano de 1964, o governo claramente adotou uma política monetária conservadora, embora seja importante ressaltar que a maior contração monetária e creditícia do ano tenha se realizado ainda sob o governo de João Goulart.

No ano de 1965, por sua vez, há uma expansão expressiva dos meios de pagamentos e do crédito ao setor privado em todos os trimestres ${ }^{8}$ (Tabela 1). Resende (1982) explica esse aumento mencionando o grande superávit obtido no balanço de pagamentos, conjugado à incapacidade da política monetária de "[...] esterilizar esse influxo de moeda gerado pelo superávit externo [...]" (RESENDE, 1989, p. 219).

A frouxidão da política monetária no ano de 1965 mostra, de um lado, a pouca efetividade da política monetária nesse momento, mas, por outro, revela também a preocupação do governo com o crescimento econômico e exclui a ideia de um plano anti-inflacionário com atributos ortodoxos. Em 1964, a economia brasileira havia apresentado um crescimento baixo (3,4\%) se comparado com os anos anteriores desde o final da década de 1950: 10,8\% em 1958; 9,8\% em 1959; 9,4\% em 1960; $8,6 \%$ em 1961; e 6,6\% em 1962. O receio de ocorrer novamente uma baixa taxa de crescimento, por certo, também influenciou na expansão monetária de 1965.

Apesar dessa política monetária expansionista, a economia brasileira cresceu apenas 2,4\% em 1965, uma taxa menor do que a apresentada no ano de 1964 (ver Tabela 2). O comportamento da política monetária e creditícia no período do Paeg ilustra bem a defasagem de seus efeitos na economia brasileira. $\mathrm{O}$ aperto monetário realizado, sobretudo, no final de 1964 foi um dos fatores importantes no baixo crescimento de 1965. E os efeitos da expansão monetária e creditícia de 1965 só vieram à tona em 1966, ano em que a economia brasileira cresceu a uma taxa de 6,7\%, mesmo com o forte aperto monetário evidenciado a partir do segundo trimestre, conforme mostrado na Tabela 1. Com o aperto monetário em 1966, simetricamente, a indústria de transformação desacelera em 1967 e apresenta uma taxa de crescimento de apenas $2,2 \%$, mesmo com as expressivas expansões do volume dos meios de pagamento e do crédito ao longo do ano. Apesar do recuo da indústria de trans-

8 O Paeg tinha previsão de expansão monetária para o ano de 1965 de $30 \%$, no entanto os meios de pagamentos naquele ano atingiram a taxa de 83,5\% (RESENDE, 1989). 
formação, o PIB da economia brasileira atinge uma taxa média de 4,2\%, mas puxado pelos setores da agropecuária e serviços, que apresentam taxas de crescimento, em 1967, de 5,7\% e 5,2\%, respectivamente, conforme a Tabela 2 .

Tabela 2 - Crescimento do PIB e principais setores de atividade: 1964-1967

\begin{tabular}{lcccc}
\hline Ano & PIB total & $\begin{array}{c}\text { PIB indústria de } \\
\text { transformação }\end{array}$ & PIB agropecuária & PIB serviços \\
\hline 1964 & $3,4 \%$ & $5,0 \%$ & $1,3 \%$ & $1,4 \%$ \\
1965 & $2,4 \%$ & $-4,7 \%$ & $12,1 \%$ & $2,2 \%$ \\
1966 & $6,7 \%$ & $11,7 \%$ & $-1,7 \%$ & $6,6 \%$ \\
1967 & $4,2 \%$ & $2,2 \%$ & $5,7 \%$ & $5,2 \%$ \\
Média & $4,2 \%$ & $3,6 \%$ & $4,4 \%$ & $3,9 \%$ \\
\hline
\end{tabular}

Fonte: Elaboração própria a partir de IPEADATA.

Os resultados da indústria de transformação do período evidenciam de forma ainda mais explícita a validade da argumentação anterior sobre o efeito defasado da política monetária e creditícia. A Figura 1 ilustra de forma nítida esse comportamento.

Figura 1 - Crescimento da indústria de transformação no Brasil (\%): 1958-1973

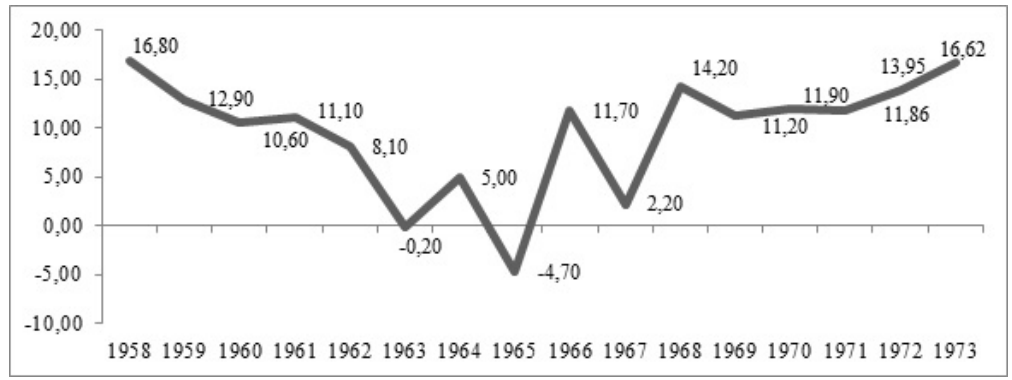

Fonte: Elaboração própria a partir de IPEADATA.

Os sucessivos apertos monetários de 1964 não resultaram em impacto negativo para a indústria de transformação naquele ano, que apresentou crescimento de 5\%, a despeito de toda a crise política que caracterizou esse período. Em 1965, por sua vez, a indústria de transformação sofreu uma queda de 4,7\%, ano em que, como já dito, houve forte expansão dos meios de pagamentos e do crédito, porém os efeitos positivos dessa política monetária e creditícia foram sentidos somente em 1966, com um crescimento de $11,7 \%$ do setor. A baixa taxa de crescimento da indústria de transformação no ano de 1967, 2,2\%, portanto, foi resultado da política monetária e creditícia contracionista do ano de 1966. 
No período em questão já existia um sistema relativamente bem articulado de crédito de fomento à atividade produtiva sobre o qual vale a pena também deter-se com o fito de compreender com maior profundidade o impacto das medidas do Paeg sobre a atividade industrial, particularmente no que diz respeito à atuação dos dois principais bancos públicos, o Banco do Brasil (BB) e o BNDE.

Em primeiro lugar, pode-se notar que os dados sobre créditos destinados ao setor industrial seguem o mesmo comportamento errático observado anteriormente para a política monetária, ainda que em proporções diversas. Em 1964, os empréstimos à indústria apresentaram uma queda real de 8,2\%; em 1965, em compasso com uma política monetária mais folgada, houve uma expansão de $24,2 \%$. Em 1966, ano do mais forte aperto monetário do Paeg, a contração real do crédito à indústria foi de 7\%, inferior ao de 1964, mas ainda assim bastante significativo. Por fim, em 1967, com Delfim Netto à frente da política econômica a partir de março, volta a se expandir com uma taxa de 18,7\% (Tabela 3). Portanto, conclui-se que, em linhas gerais, a disponibilidade de crédito usufruída pelo setor industrial acompanhou as tendências constatadas para a política monetária, sem que esse setor tenha desfrutado de posição privilegiada ou discriminatória, em vista, provavelmente, de uma perspectiva neutra da indústria por parte da equipe econômica relativamente aos demais setores da economia.

Tabela 3 - Sistema bancário: empréstimos à indústria, saldos de fim de ano

\begin{tabular}{|c|c|c|c|}
\hline \multirow{2}{*}{ Anos } & \multirow{2}{*}{ NCr\$ milhões } & \multicolumn{2}{|c|}{ \% Variação } \\
\hline & & Nominal & Real $(*)$ \\
\hline 1963 & 795 & - & - \\
\hline 1964 & 1.401 & 76,2 & $-8,2$ \\
\hline 1965 & 2.341 & 67,1 & 24,2 \\
\hline 1966 & 3.031 & 29,5 & $-7,0$ \\
\hline 1967 & 4.479 & 47,8 & 18,7 \\
\hline
\end{tabular}

Fonte: Banco do Brasil (1968).

Nota: "Deflator: índice geral de preços da Fundação Getúlio Vargas (dezembro a dezembro), base de $1963=100$.

Uma das formas de avaliar em que medida a última afirmativa pode ou não ser corroborada seria analisar a atuação específica do BB e do BNDE, importantes instrumentos de crédito diretamente vinculados às autoridades econômicas. Assim, analisando de forma mais pormenorizada a política creditícia, manifestam-se alguns fatos interessantes que valem a pena ser ressaltados.

Relativamente ao BB, os dados da Tabela 4 demonstram que não é possível afirmar que os empréstimos realizados ao setor privado pelo banco estavam alinhados com a totalidade dos empréstimos realizados pelos bancos comerciais. 
Tabela 4 - Sistema bancário: empréstimos ao setor privado em termos reais (Cr\$ milhões - 1965/1967 = 100: posição final de período) e variação (\%)

\begin{tabular}{l|c|c|c|c|c|c}
\hline Anos & \multicolumn{2}{|c|}{ Bancos comerciais } & \multicolumn{2}{c|}{ Banco do Brasil } & \multicolumn{2}{c}{ Total } \\
\hline & $\begin{array}{l}\text { Em Cr\$ } \\
\text { milhões }\end{array}$ & $\begin{array}{c}\text { Variação } \\
\text { (\%) }\end{array}$ & $\begin{array}{c}\text { Em Cr\$ } \\
\text { milhões }\end{array}$ & $\begin{array}{c}\text { Variação } \\
\text { (\%) }\end{array}$ & $\begin{array}{c}\text { Em Cr\$ } \\
\text { milhões }\end{array}$ & $\begin{array}{c}\text { Variação } \\
\text { (\%) }\end{array}$ \\
\hline 1963 & 3.903 & - & 3.462 & - & 7.365 & - \\
1964 & 3.745 & $-4,05$ & 2.149 & $-37,93$ & 5.894 & $-19,97$ \\
1965 & 4.924 & 31,48 & 1.978 & $-7,96$ & 6.902 & 17,10 \\
1966 & 4.410 & $-10,44$ & 2.236 & 13,04 & 6.646 & $-3,71$ \\
1967 & 5.834 & 32,29 & 2.496 & 11,63 & 8.330 & 25,34 \\
\hline
\end{tabular}

Fonte: Resende (1982)

A contração realizada pelo BB em 1964 foi muito superior em termos relativos $(-37,93 \%)$ do que a realizada pelos outros bancos comerciais $(-4,05 \%)$ e também pela totalidade dos empréstimos ao setor privado (-19,97\%). No ano seguinte, em 1965, enquanto os bancos comerciais expandem seus empréstimos em 31,48\% o BB contrai quase $8 \%$ em relação ao ano anterior. Em 1966, por sua vez, a situação se inverte com o BB ampliando seus empréstimos (13,04\%) ao setor privado e os bancos comerciais contraindo em $10,44 \%$. Ademais, o não alinhamento da expansão do BB, no ano de 1966, não se restringe aos empréstimos realizados pelos bancos comerciais, mas também à liquidez real medida pela expansão monetária (ver Tabela 1). No último ano do Paeg, pode-se afirmar que há um alinhamento entre os empréstimos realizados pelo $\mathrm{BB}$ e os bancos comerciais, com uma maior expansão feita por estes últimos.

Em relação à atuação do BNDE durante o período do Paeg, pode-se verificar, na Tabela 5, que o total de recursos com os quais ele pôde contar triplicou em termos reais entre 1964 e 1967.

Tabela 5 - Recursos mobilizados pelo BNDE: 1964-1967

\begin{tabular}{lcc}
\hline Ano & Recursos do BNDE (Cr\$ milhões) & Variação real $^{*}$ \\
\hline 1964 & 174.900 & $1,9 \%$ \\
1965 & 614.379 & $158,2 \%$ \\
1966 & 828.461 & $-1,6 \%$ \\
1967 & 1.204 .000 & $16,9 \%$ \\
\hline
\end{tabular}

Fonte: Prochnik (1995) apud Tavares et al. (2010, p. 123).

Nota: * Deflacionado pelo IGP-DI. 
Esse aumento expressivo deve-se sobretudo à

[...] modificação introduzida ainda em 1964, pela Lei no 4.506, de 30 de novembro, que extinguia, a partir de 1965, o Adicional ao Imposto de Renda. Em contrapartida, esses recursos, que haviam sido tão importantes na trajetória do Banco, foram substituídos pela destinação de $20 \%$ da arrecadação do Imposto de Renda a seus cofres (TAVARES et. al., 2010, p. 123).

Tal mudança representou, só em 1965, uma expansão de mais de 150\% dos recursos reais à disposição do BNDE. Todavia, há que se notar também que, acompanhando-se o movimento já observado para a política monetária, em 1966, ocorre uma redução do valor real dos empréstimos de 1,6\%, percentual bastante reduzido, sobretudo se levado em conta a enorme ampliação observada no ano anterior. Em 1967, há uma forte recuperação com o aumento de 16,9\%. Isso evidencia que, “[...] apesar de suas convicções ortodoxas, durante o período em que Bulhões e Campos estiveram no comando da política econômica brasileira, os recursos disponíveis para o BNDE cresceram de forma expressiva [...]" (TAVARES et al., 2010, p. 129). Tal elevação dos recursos mobilizados pelo BNDE decerto atenuou de forma oportuna a restrição que se operava no âmbito estrito da política fiscal.

Além desse aumento substancial de recursos com os quais o BNDE passa a contar, pode-se constatar também durante esse período uma nítida mudança de perfil de atuação, reduzindo-se fortemente a participação relativa dos empréstimos destinados a investimentos em serviços de utilidade pública em favor da destinação de recursos para a indústria, com destaque particular, dentro desta, para o setor siderúrgico, conforme mostrado na Tabela 6.

Tabela 6 - BNDE: operações em moeda nacional aprovadas, segundo as atividades econômicas beneficiadas: 1952-1967 (médias da distribuição percentual por período)

\begin{tabular}{|c|c|c|c|c|c|c|c|}
\hline \multirow[b]{2}{*}{ Ano } & \multicolumn{3}{|c|}{ Serviços de utilidade pública } & \multicolumn{3}{|c|}{ Indústria } & \multirow{2}{*}{$\begin{array}{c}\text { Outras } \\
\text { atividades }\end{array}$} \\
\hline & $\begin{array}{l}\text { Transportes e } \\
\text { comunicações }\end{array}$ & Energia & $\begin{array}{c}\text { Subtotal } \\
\text { elétrica }\end{array}$ & Siderúrgica & Diversos & Subtotal & \\
\hline $1952-1960$ & 48,4 & 30,1 & 69,8 & 17,5 & 16,5 & 31,8 & 2,1 \\
\hline 1961-1963 & 1,1 & 29,7 & 30,4 & 54,6 & 12,0 & 66,6 & 3,0 \\
\hline $1964-1967$ & 0,2 & 14,5 & 14,6 & 55,5 & 27,2 & 82,6 & 2,8 \\
\hline
\end{tabular}

Fonte: Tavares et al. (2010, p. 123).

Nota: A partir de 1965, o total inclui as operações do Fundo de Financiamento para Aquisição de Máquinas e Equipamentos Industriais (Finame), cujos valores não são distribuídos pelas atividades econômicas.

Assim, se nos primeiros anos do BNDE, até 1960, os investimentos em infraestrutura correspondiam a mais de dois terços dos desembolsos, tal percentual já havia se reduzido fortemente no início dos anos 1960 e perde ainda mais participação nos 
anos do Paeg. Em contrapartida, o grande beneficiário foi o setor siderúrgico, que passou a receber, nos anos 1960, mais da metade dos empréstimos do banco.

Na sequência, como principal beneficiário dessa mudança de atuação, surge a indústria de transformação, a qual passa a receber mais de um quarto dos recursos totais.

Os dados apresentados relativamente à disponibilidade de crédito ao setor industrial explicam, ao menos em parte, a evolução da taxa de investimento total da economia brasileira nesse período.

Os investimentos do setor privado, analisados pela formação bruta de capital fixo, evidenciam a ideia dos impactos defasados, explicada anteriormente, da política monetária. Aqui, mais especificamente, dos impactos dos empréstimos à indústria (ver Tabela 3) no comportamento dos investimentos. Em três dos quatro anos em que o Paeg se insere, 1964, 1965 e 1967, houve diminuição dos investimentos (ver Tabela 7). Em contrapartida, em 1966, o investimento do setor privado cresceu $51,14 \%$, ano em que a indústria de transformação apresentou maior crescimento no período, 11,7\%, (ver Tabela 2) e que, no ano anterior, 1965, os empréstimos à indústria haviam crescido $24,2 \%$.

Tabela 7 - Formação bruta de capital fixo (FBKF): máquinas e equipamentos, investimento privado (1962-1968)

\begin{tabular}{l|ccc}
\hline \multirow{2}{*}{ Ano } & \multicolumn{3}{|c}{ Empresas e famílias } \\
\cline { 2 - 4 } & $\begin{array}{c}\text { Em milhões de R\$ de } \\
\mathbf{1 9 9 9}\end{array}$ & Variação real (\%) & $\begin{array}{c}\text { FBKF como porcentagem } \\
\text { do PIB (\%) }\end{array}$ \\
\hline 1962 & $10.315,31$ & & 5,28 \\
1963 & $10.890,70$ & 5,58 & 5,85 \\
1964 & $9.831,19$ & $-9,73$ & 4,72 \\
1965 & $9.558,05$ & $-2,78$ & 4,11 \\
1966 & $14.446,28$ & 51,14 & 5,30 \\
1967 & $13.852,76$ & $-4,11$ & 4,52 \\
1968 & $18.803,07$ & 35,74 & 5,60 \\
\hline
\end{tabular}

Fonte: Elaboração própria a partir de IBGE - Estatísticas do século XX.

No entanto, comparando-se a variação dos investimentos privados com os resultados da indústria de transformação, não se pode afirmar um total alinhamento, ou uma relação totalmente direta entre aumento do investimento privado e crescimento da indústria de transformação para o período. Em 1964, o investimento privado apresentou uma queda de 9,73\% (ver Tabela 7) e a indústria de transformação cresceu 5\% (ver Tabela 2). A partir de 1965, consegue-se observar um relativo alinhamento entre as duas variáveis. Em 1965, houve uma diminuição nos investimentos, o que resultou em queda da indústria de transformação. Em 
1966, os investimentos aumentaram de maneira significativa $(51,14 \%)$ e a indústria de transformação apresentou crescimento de $11 \%$. Em 1967, por sua vez, a indústria de transformação, aproveitando ainda o alto investimento do ano anterior, cresceu $2,2 \%$, mesmo com a diminuição de $4,11 \%$ dos investimentos no ano. ${ }^{9}$

No agregado, em relação ao total produzido pela economia, os resultados apresentados não foram positivos para a indústria de transformação durante o Paeg. A participação do setor no PIB brasileiro apresentou uma tendência de queda no período, no sentido contrário do observado em anos anteriores e posteriores ao Paeg. A Figura 2 ilustra de maneira mais clara esse fenômeno.

Figura 2 - Participação da indústria de transformação no PIB brasileiro (\%)



Fonte: Elaboração própria a partir de IPEADATA.

Desde os anos 1930, num processo que se intensifica na década de 1950, e até o início dos anos 1960, a indústria de transformação apresenta uma trajetória ascendente em sua participação no total produzido na economia. Isso não se aplica ao período do Paeg (1964-1967), período no qual há uma queda da participação do setor no PIB. A indústria de transformação só volta a ganhar participação no PIB a partir de 1968, já em plena efervescência do "milagre econômico" (Figura 2).

Enquanto a indústria de transformação cresceu em média 3,55\% entre os anos de 1964-1967, outros setores apresentaram crescimento maior. Isso explica a perda de participação do setor da indústria de transformação na produção total da economia. O setor de comércio e serviços teve um crescimento médio no período de 3,73\%, o setor da construção civil, de 5,93\%, o setor agropecuário, de 4,35\% e a indústria extrativa, de $12,38 \%$.

9 Um dado adicional que certamente seria importante para nossa análise seria a disponibilidade de crédito ao consumidor durante o período 1964-1967. Todavia, não foi possível proceder ao levantamento desses dados, muito provavelmente por conta do caráter ainda incipiente das reformas financeiras realizadas pelo Paeg. 
Tal comportamento desfavorável do setor industrial vis-à-vis os demais setores encontra-se, segundo o ponto de vista deste estudo, intimamente relacionado ao comportamento da política de estabilização implementada entre 1964 e 1967.

Para Resende (1982), a ortodoxia do Paeg resumiu-se na política monetária efetivada na segunda metade de 1964 e 1966 e início de 1967. A política creditícia, mesmo nesses momentos de maior aperto monetário, revelou-se apenas neutra. Nos demais trimestres do Paeg, cerca de dois terços do período, tanto a política monetária quanto a creditícia foram na verdade expansionistas, ao contrário da política fiscal strictu sensu, que se caracterizou como restritiva durante os anos do Paeg, com elevação dos impostos e redução das despesas do governo, conforme a Tabela 8.

Tabela 8 - Tesouro nacional: receita e despesa (\%) do PIB

\begin{tabular}{llll}
\hline Ano & Receita & Despesa & Déficit \\
1963 & 8,8 & 13,0 & 4,2 \\
1964 & 9,2 & 12,4 & 3,2 \\
1965 & 10,6 & 12,2 & 1,6 \\
1966 & 11,0 & 12,1 & 1,1 \\
1967 & 9,5 & 11,2 & 1,7 \\
\hline
\end{tabular}

Fonte: Resende (1982, p. 781).

De 1963 até 1967, as despesas do governo foram diminuindo em relação ao PIB, enquanto a receita apresentou crescimento entre 1963 e 1966; somente em 1967 a tendência de alta da arrecadação é freada.

A desaceleração da atividade industrial está relacionada, segundo Resende (1982), com as restrições em conjunto das políticas fiscal, monetária e creditícia. Nas palavras do autor: "É nítida, na experiência brasileira do período em questão, a relação entre as políticas fiscal, monetária e creditícia restritivas, principalmente esta última, e a desaceleração da atividade industrial [...]" (RESENDE, 1982, p. 790). Não obstante, cabe frisar que se alude, no conjunto do período do Paeg, a uma desaceleração relativa ao período anterior, e não a uma recessão industrial - à exceção, como visto, do ano de 1965, quando o produto industrial regrediu quase $5 \%$, seguindo-se um forte crescimento no ano seguinte. O crescimento médio do PIB de $4,2 \%$ e de 3,55\% da indústria tolhe de forma contundente a interpretação de que a contenção da demanda foi o fator crucial para o sucesso da política anti-inflacionária do Paeg. A política salarial fortemente restritiva, ao lograr uma redução de custos expressiva para as empresas - assim como para o governo -, indubitavelmente adquire muito maior relevância na elucidação das razões que levaram à redução dos índices inflacionários no período.

Observando de forma geral o plano, Martone (1984) faz uma análise crítica das políticas econômicas adotadas no Paeg. Segundo o autor, as duas formas de com- 
bate à inflação eram a diminuição do déficit orçamentário do governo, por meio do aumento da arrecadação, e a contenção dos salários. O primeiro fator não teve efeitos totalmente favoráveis, pois, com o aumento dos tributos, as empresas transferiam esse custo adicional para os preços dos produtos, criando, assim, uma pressão de custos sobre a inflação. A demanda foi contida pela diminuição do salário real, visto que a inflação alcançou patamares superiores às previsões do governo e parte da correção salarial era feita com base na inflação oficial prevista. Os salários reais foram reduzidos e os assalariados que tiveram seus salários corrigidos exclusivamente pela política salarial viram seu poder de compra degradar-se.

O autor é mais duro com o Paeg e sua política monetária, defendendo que as crises conjunturais violentas que a economia brasileira passou no período foram fruto da instabilidade da política monetária:

De fato, a carência de crédito imposta pelo Governo fez com que as empresas fossem levadas a um estado precário de liquidez que, ao lado dos demais fatores contrários já apontados pelo lado da demanda e custos, produzia a recessão. Quando a crise já se encontrava em seus pontos mais baixos, o Governo, no intuito de prevenir males maiores, liberalizava sua política monetária e injetava na economia novos meios de pagamento, fazendo subir de novo o nível de atividade e melhorando a liquidez do sistema. Uma vez superada a crise, entretanto, voltava o rígido controle dos meios de pagamento, motivado pelo receio de que a inflação monetária escapasse novamente das mãos do Governo. Uma nova crise assim se esboçava e assim sucessivamente (MARTONE, 1984, p. 85).

Na seção seguinte, é feito o exame com maior acuidade dos impactos dessas oscilações da política econômica, sobretudo das políticas monetária e creditícia sobre os subsetores mais importantes da indústria.

\section{A Política Monetária e Creditícia e os Efeitos Setoriais na Indústria}

O item anterior discorreu como as políticas monetárias e creditícias do Paeg afetaram o desempenho geral da economia brasileira e a indústria de transformação em particular. Nesta seção, são analisados os efeitos setoriais dessas políticas, pois acredita-se que esse tipo de análise sobre o período 1964-1967 foi pouco explorado na literatura em geral.

Inicialmente, é feito um exame mais geral referente a todos os setores da indústria de transformação para, em seguida, explorar-se com grau maior de minúcia alguns dos principais setores da indústria de transformação. 


\subsection{Impacto Setorial do Paeg: uma Perspectiva Geral}

Uma visão panorâmica sobre o impacto que o Paeg teve sobre o setor industrial pode ser depreendida da Tabela 9.

Tabela 9 - Índices do volume físico da produção industrial: 1963-1967

\begin{tabular}{l|c|c|c|c|c}
\hline \multirow{2}{*}{ Especificação } & \multicolumn{5}{|c}{ Índices (1962 = 100) } \\
\cline { 2 - 6 } & $\mathbf{1 9 6 3}$ & $\mathbf{1 9 6 4}$ & $\mathbf{1 9 6 5}$ & $\mathbf{1 9 6 6}$ & $\mathbf{1 9 6 7}$ \\
\hline Indústria de transformação & 99,7 & 104,8 & 99,9 & 112,1 & 114,8 \\
Transformação de minerais não metálicos & 99,9 & 105,6 & 95,5 & 104 & 112,9 \\
Metalúrgica & 103,4 & 109,7 & 105,5 & 130,3 & 127,1 \\
Mecânica & 102,6 & 104,1 & 91,5 & 93,1 & 88,1 \\
Material elétrico e de comunicações & 96,1 & 105,1 & 116,3 & 145,8 & 159,7 \\
Material de transporte & 89,3 & 92,3 & 91,7 & 113,6 & 113,8 \\
Madeira & 102,5 & 105,5 & 83,5 & 76,3 & 77,9 \\
Papel e papelão & 107,8 & 114,8 & 112,2 & 123 & 142,6 \\
Borracha & 100,9 & 107,6 & 101,3 & 128,6 & 139,2 \\
Couros e peles e produtos similares & 92,8 & 102,1 & 132,4 & 111,2 & 121,1 \\
Química ${ }^{(1)}$ & 103,6 & 113,9 & 109,7 & 126,6 & 130,9 \\
Têxtil & 97,3 & 101,6 & 85,2 & 81,1 & 79,5 \\
Vestuário, calçados e artefatos de tecidos & 100,8 & 113,1 & 100,8 & 114,9 & 108,3 \\
Produtos alimentares & 99,2 & 100,6 & 95,8 & 100,4 & 107,7 \\
Bebidas & 102,0 & 91,3 & 99,2 & 119,1 & 104,3 \\
Fumo & 100,5 & 99,2 & 94,5 & 96,9 & 106,2 \\
Indústria extrativa mineral & 106,9 & 108,9 & 119,2 & 137,9 & 159,7 \\
Indústria de construção civil & 101,3 & 103,5 & 78,7 & 83,3 & 91,1 \\
Indústria de energia elétrica & 102,6 & 110,0 & 114,6 & 125,4 & 131,5 \\
\hline & 100,2 & 105,4 & 100,4 & 112,1 & 115,4 \\
\hline & & & & \\
Fonte: & & & &
\end{tabular}

Fonte: Instituto Brasileiro de Geografia e Estatística (1968, p. 175).

Nota: $\left(^{1}\right)$ Inclui indústria química, petroquímica e de produtos de perfumaria, sabões e velas.

O índice do volume físico de produção evidencia que, a despeito da crise política aguda que marcou o ano de 1964 e que culminou com o golpe militar, a indústria de transformação como um todo se expandiu pouco mais de $5 \%$. Tal evolução positiva ocorreu de forma generalizada, à exceção da indústria de fumo e de bebidas (esta apresentando uma queda de mais de 10\% em relação a 1963).

Esse desempenho pode estar relacionado a dois fatores. Primeiro à recessão industrial observada em 1963, o que fez com que a "base de cálculo" para o ano 
seguinte fosse mais diminuta e, por outro lado, à política monetária acomodatícia implementada no final do governo Goulart, paralelamente ao montante ainda elevado do déficit público na fase inicial das medidas contencionistas e da reforma tributária. É importante frisar que tal comportamento positivo se estendeu à indústria extrativa mineral, construção civil e energia elétrica.

Já em 1965, provavelmente como resultado do relativo aperto monetário e creditício implementado no final do ano anterior e, sobretudo, da política fiscal bem mais restritiva, o desempenho do setor industrial foi decepcionante, com queda de quase 5\%. Entre os setores mais atingidos destacam-se: madeira, têxtil, mecânica e vestuário, calçados e artefatos de tecido, com índices negativos na casa de dois dígitos. Apenas três setores foram exceções: couros e peles e produtos similares, material elétrico e de comunicações e bebidas (este último setor não consegue, todavia, recuperar o nível de produção perdido em 1964). É possível também identificar nesse ano um conjunto de setores industriais mais sofisticados tecnologicamente e que foram menos impactados pela crise que atingiu o setor industrial, entre os quais: material de transporte, papel e papelão, química e metalúrgica.

Conforme apontado, a política monetária foi fortemente expansionista em 1965, tornando-se restritiva a partir de meados de 1966 (até o início do ano seguinte). Já a política creditícia mostrou resultados menos voláteis, foi expansionista, mas menos intensamente que a política monetária em 1965, tornando-se neutra a partir de meados de 1966. Esse comportamento de ambas as políticas, levando-se em consideração a existência de uma defasagem em torno de seis meses a um ano para que seus efeitos se façam sentir, se coaduna quase à perfeição com o comportamento da maior parte dos setores industriais em 1966 e 1967.

Em 1966, a despeito da política monetária restritiva na segunda metade do ano, a indústria de transformação cresceu mais de $12 \%$ (IBGE, 1968). Os principais setores que se beneficiaram da expressiva expansão monetária em 1965 e até o início de 1966 foram principalmente setores com maior densidade de capital: borracha, material elétrico e de comunicações, material de transporte (no qual se inclui o setor automobilístico), metalurgia e bebidas (que dá continuidade à expansão observada no ano anterior).

O Paeg, embora formalmente encerrado em março de 1967, com a posse do governo Costa e Silva estende seus efeitos para a maior parte desse ano, mesmo quando considerada a virada eloquente na política econômica operada a partir da posse de Delfim Netto como Ministro da Fazenda. Assim, o crescimento do volume físico da produção industrial nesse ano foi bastante modesto em virtude da política contencionista praticada desde meados de 1966 até o primeiro trimestre de 1967, sendo pouco inferior a 2,5\%. Ainda assim, é possível identificar setores nos quais o desempenho foi bastante significativo: papel e papelão, fumo, material elétrico e de comunicações, couros, peles e produtos similares e transformação 
de minerais não metálicos. Por outro lado, cinco setores foram atingidos negativamente: bebidas (novamente), vestuário, calçados e artefatos de tecidos, mecânica, metalurgia e têxtil. A presença relevante de setores ligados ao consumo popular permite estabelecer a hipótese de que os resultados negativos desses setores em particular estejam relacionados aos efeitos mais intensos da política salarial, a qual promoveu, entre 1965 e 1967, uma redução expressiva no nível do salário real de todos os trabalhadores, tanto do setor público quanto do setor privado, que viram seus rendimentos corrigidos pela fórmula vigente.

Feitas essas considerações setoriais mais gerais, resta analisar, com maior acurácia e com base em dados provenientes de outras fontes, alguns setores industriais mais relevantes.

A escolha dos setores automobilístico, siderúrgico e de cimento deve-se a duas razões fundamentais conjugadas: significativa importância relativa no conjunto da atividade industrial do período - ressaltando-se seus importantes efeitos de encadeamento sobre a estrutura produtiva - e maior disponibilidade de informações quantitativas e qualitativas.

\subsection{Indústria Automobilistica}

O setor automobilístico não apresentou retração durante o período do Paeg. Pelo contrário, apresentou taxas de crescimento, conforme pode-se constatar nas Tabelas 10 e 11 . O comportamento positivo da produção e das vendas do setor entre os anos de 1964 e 1967 se deve ao fato de que, na década de 1960, a indústria de automóvel no país era relativamente nova e atendia uma demanda da classe média brasileira por carros que ainda estava reprimida. É importante lembrar que a produção nacional de veículos se iniciou apenas a partir de 1957 e, portanto, os automóveis vendidos no mercado nacional eram até então apenas os importados e, devido às altas tarifas aduaneiras de importação e a parcimônia extrema com a qual o governo brasileiro lidava com as parcas divisas disponíveis, esse tipo de bem tinha uma oferta diminuta e era muito caro, sendo passível de compra por uma parcela muito restrita da sociedade brasileira. Os preços mais acessíveis, a partir de 1957, ampliaram o mercado consumidor de automóveis. Dessa forma, mesmo com a crise econômica instalada a partir de 1963 e as políticas de estabilização do Paeg, o setor automobilístico continuou apresentando evolução positiva durante o governo Castello Branco. 


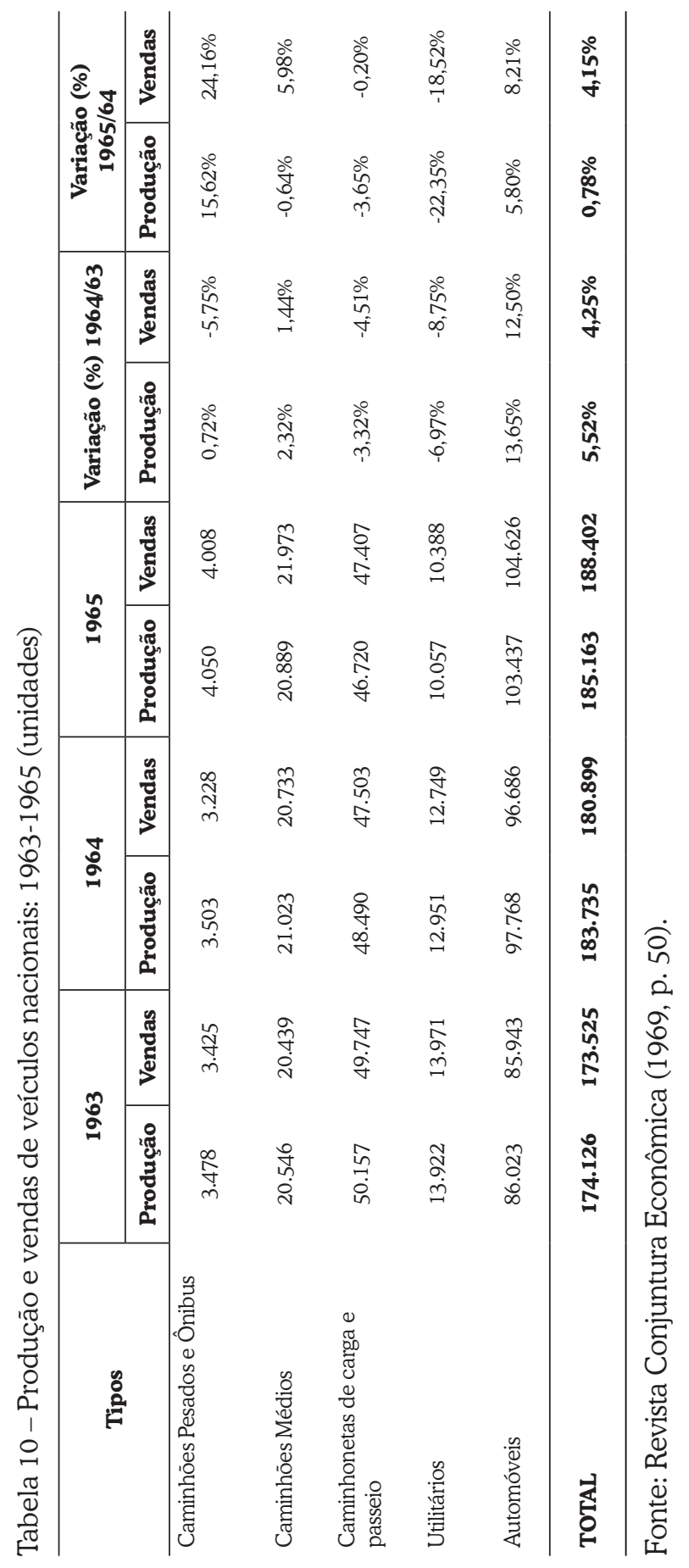

Análise Econômica, Porto Alegre, v. 39, n. 78, p. 177-206, mar. 2021. 


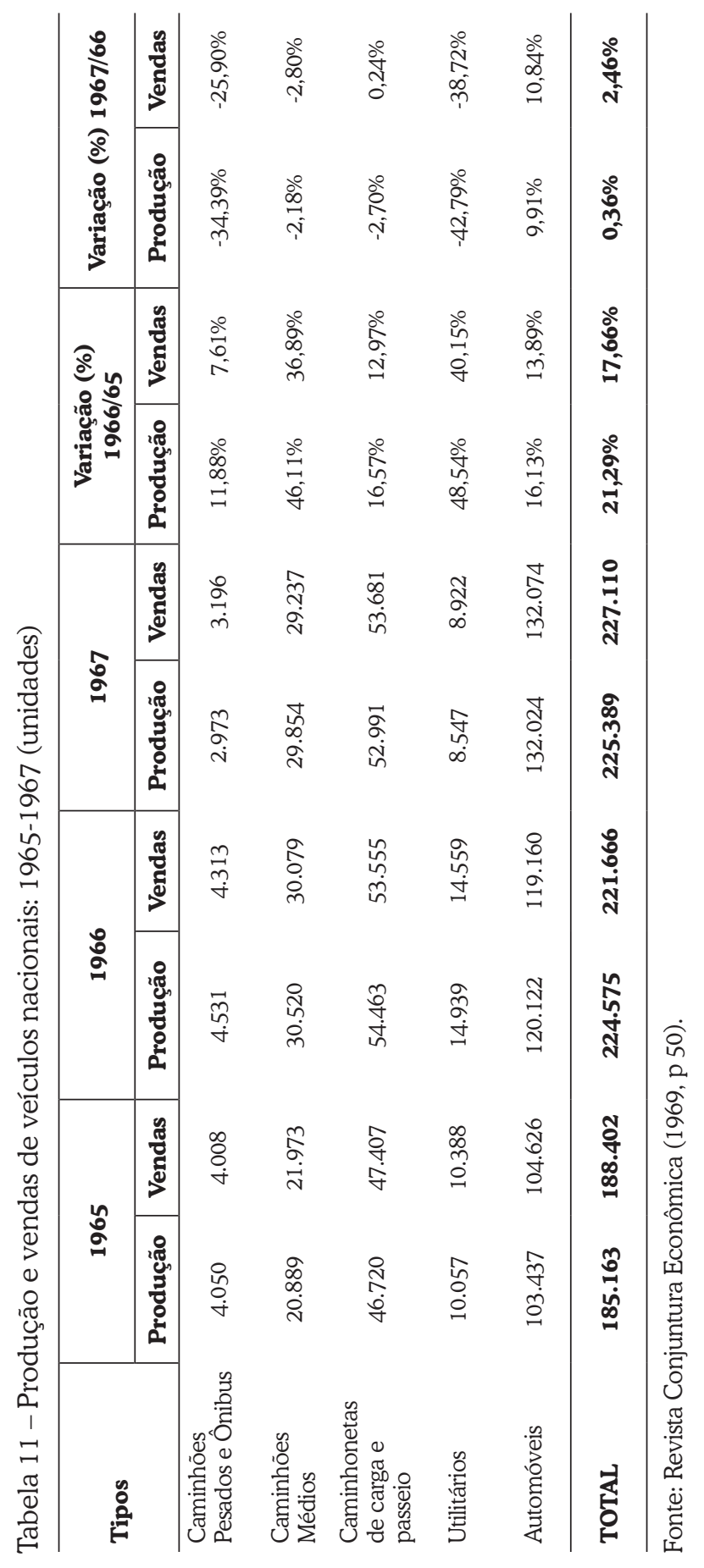


Conforme pode-se observar na Tabela 10, no primeiro ano do programa de estabilização, 1964, a produção da indústria automobilística cresceu 5,52\% e as vendas tiveram um aumento de $4,25 \%$. Essas taxas superaram o crescimento do PIB do ano $(3,4 \%)$ e acompanharam o crescimento da taxa da indústria de transformação (5\%).

O ano de 1965, por sua vez, foi também positivo para o setor automobilístico, mas cresceu pouco (produção: $0,78 \%$; vendas: $4,15 \%$ ) se comparado ao ritmo do período anterior. Entre os anos de 1960 e 1964, a taxa média de crescimento da produção e das vendas foram $9,33 \%$ e $9,11 \%$, respectivamente. A baixa taxa de crescimento no ano de 1965 não foi característica específica do setor de automóveis. A indústria de transformação apresentou resultados piores, com uma queda considerável de $4,7 \%$ no ano. Como explicado no item anterior, o aperto da política monetária de 1964 impactou negativamente a indústria de transformação no ano seguinte. No entanto, a demanda para automóveis e outros bens duráveis foi estimulada por políticas do governo. Os principais estímulos foram a redução do imposto do consumo incidente sobre a produção e a facilitação do financiamento para aquisição de automóveis pelas agências da Caixa Econômica Federal (REVISTA CONJUNTURA ECONÔMICA, 1969, p. 51). Essas duas políticas garantiram o resultado positivo do setor automobilístico. ${ }^{10}$

O ano de 1966 foi o mais próspero para a indústria automobilística. O afrouxamento das políticas monetária e creditícia de 1965 impactou positivamente na produção e venda de automóveis. A produção cresceu $21,29 \%$ e as vendas cresceram $17,60 \%$ (ver Tabela 11), o que representou um crescimento do faturamento entre 1965 e 1966 de 14,28\% das fábricas de automóveis, conforme a Tabela 12.

Tabela 12 - Faturamento real das fábricas de automóveis em NCR \$ de 1967

\begin{tabular}{lcc}
\hline Ano & Faturamento & Variação \% \\
\hline 1963 & 1.792 .197 & \\
1964 & 1.932 .059 & 7,80 \\
1965 & 1.690 .937 & $-12,48$ \\
1966 & 1.932 .360 & 14,28 \\
1967 & 2.143 .408 & 10,92 \\
\hline
\end{tabular}

Fonte: Revista Conjuntura Econômica (1969)

Outro indicador relevante que expressa o comportamento do nível de produção de um setor é o consumo de energia elétrico associado a ele. De 1964 até 1967, o consumo de energia elétrica do setor automobilístico, nos estados de São

10 O setor automobilístico possui grande importância para o agregado da economia, pois possui ligação direta e estimula outros setores industriais, como metalúrgica, vidro, plástico, borracha, material elétrico, mecânica, química, etc. (REVISTA CONJUNTURA ECONÔMICA, 1969, p. 55). 
Paulo e Rio de Janeiro, cresceu na maioria dos anos, exceto no ano de 1967, em que a produção de veículos automotores apresentou seu pior resultado no período com um crescimento de apenas 0,36\%, conforme a Figura 3.

Figura 3 - Consumo industrial de eletricidade no setor automobilístico: Rio de Janeiro e São Paulo (1.000 kWh)



Fonte: Elaboração própria a partir de Revista Conjuntura Econômica (1965, 1966, 1967, 1968).

Além da reduzida taxa de crescimento da produção em 1967, as vendas cresceram apenas 2,5\%. Os efeitos no ano de 1967 do aperto monetário de 1966 na indústria de automóvel seguiu o que ocorreu com o agregado da indústria de transformação: uma baixa taxa de crescimento $(2,2 \%)$. A contração da moeda em 1966 foi a mais forte do Paeg. As vendas de automóveis, como observado anteriormente, cresceram pouco, porém o faturamento das fábricas de automóveis cresceu 10,92\%, uma taxa muito maior do que o aumento das vendas de veículos, o que está a indicar uma elevação no valor médio dos automóveis comercializados.

Retomando-se as Tabelas 10 e 11, pode-se observar que os automóveis puxaram a produção e as vendas do setor automobilístico no período, apresentando taxas de crescimento significativas em todos os anos, com destaque para o ano de 1966, no qual se observa uma elevação de 16,13\% na produção e de 13,89\% nas vendas. Por outro lado, os outros tipos de automotores tiveram retrações em alguns anos em suas produções e vendas. Vale destacar o ano de 1967, no qual os setores de caminhões pesados e ônibus e de utilitários apresentaram fortes quedas. O primeiro regrediu 34,39\% na produção e 25,9\% nas vendas. Os automóveis utilitários recuaram 42,79\% na produção e 38,72\% nas vendas. As vendas de caminhões pesados e ônibus, caminhões médios e caminhonetas de carga são bons indicadores para expressar o desempenho da economia. Analisando-se esses itens, pode-se constatar que só o ano de 1966 teve um resultado positivo expressivo para os dois tipos de veículos e o ano de 1965, para caminhões pesados e ônibus. Para os outros anos, houve retração ou baixo crescimento, o que se coaduna com o comportamento da indústria de transformação no período. 


\subsection{Indústria Siderúrgica}

O setor siderúrgico brasileiro no período do Paeg acompanhou o desempenho da indústria de transformação e as oscilações das políticas monetárias e creditícias, apresentando resultados positivos em 1964 e 1966, retração em 1965 e praticamente uma estagnação em 1967. Tais oscilações e o comportamento negativo em 1965 e 1967 ocorreram a despeito do apoio financeiro propiciado pelo BNDE, conforme apontado, evidenciando provavelmente que as condições de demanda, aqui especificamente, se mostraram mais importantes que as condições de financiamento ao setor.

A indústria siderúrgica em 1964 cresceu 8,22\%, produzindo 3.043,7 toneladas de lingotes de aço. O ano de 1965 apresentou uma retração de 2,16\% em relação ao ano anterior, com a produção diminuindo para 2.978,1 toneladas. A maior expansão do setor siderúrgico foi em 1966, uma vez que a produção subiu de $2.978,1$ toneladas de lingotes de aço para 3.766,7, o que representa um crescimento de 26,48\% na produção, conforme a Tabela 13 .

Tabela 13 - Evolução da produção brasileira de aço: toneladas de lingotes (unidade: $1.000 \mathrm{t}$ )

\begin{tabular}{lll}
\hline Ano & Produção & \% Variação \\
\hline 1963 & $2.812,4$ & - \\
1964 & $3.043,7$ & 8,22 \\
1965 & $2.978,1$ & $-2,16$ \\
1966 & $3.766,7$ & 26,48 \\
1967 & $3.720,4$ & $-1,23$ \\
\hline
\end{tabular}

Fonte: Revista Conjuntura Econômica (1971).

O ano de 1967 apresentou uma pequena retração de 1,23\%. O desempenho da produção da indústria siderúrgica foi acompanhado pelo comportamento do consumo de eletricidade do setor. Em 1965, o consumo de eletricidade das empresas de siderurgia decresceu $11,1 \%$. Por sua vez, em 1966 o consumo vai de 797,89 mi de $\mathrm{kWh}$ para 990.236, o que representa um aumento no consumo de $24,1 \%$, taxa muito parecida ao do aumento ocorrido na produção de aço no ano (26,48\%). Em 1967, o consumo de energia elétrica sofre pequena retração de 0,1\% saindo de 990,2 para 989,7 mi de kWh, conforme a Figura 4. 
Figura 4 - Consumo industrial de eletricidade no setor siderúrgico: Rio de Janeiro e São Paulo (1.000 kWh)

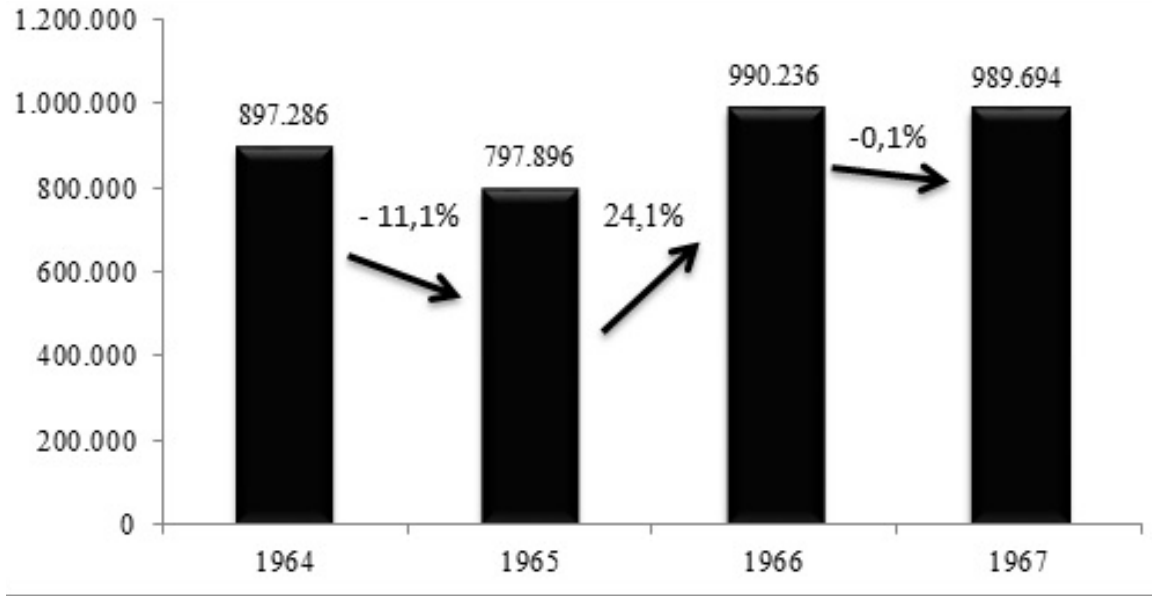

Fonte: Revista Conjuntura Econômica (1965, 1966, 1967, 1968).

\subsection{Indústria de Cimento}

A indústria de cimento não apresentou retração no período do Paeg, conforme pode ser visto na Tabela 14 .

Tabela 14 - Produção e consumo aparente de cimento: Brasil (1963-1967)

\begin{tabular}{l|c|c|c|c|c|c|c}
\hline \multirow{2}{*}{ Ano } & \multicolumn{4}{|c|}{ Cimento* } & & & \\
\cline { 2 - 8 } & $\begin{array}{c}\text { Produção } \\
\text { (mil t) }\end{array}$ & $\begin{array}{c}\text { Variação } \\
\text { (\%) }\end{array}$ & $\begin{array}{c}\text { Consumo } \\
\text { aparente } \\
\text { (mil t) }\end{array}$ & $\begin{array}{c}\text { Variação } \\
\text { (\%) }\end{array}$ & $\begin{array}{c}\text { Consumo per } \\
\text { capita } \\
\text { (Kg/habitante) }\end{array}$ & $\begin{array}{c}\text { Exportação } \\
\text { (mil t) }\end{array}$ & $\begin{array}{c}\text { Importação } \\
\text { (mil t) }\end{array}$ \\
\hline 1963 & 5.188 & & 5.210 & & 68 & 3 & 8 \\
1964 & 5.583 & 7,61 & 5.586 & 7,22 & 71 & $\ldots$ & 29 \\
1965 & 5.624 & 0,73 & 5.673 & 1,56 & 70 & 3 & 43 \\
1966 & 6.046 & 7,50 & 6.125 & 7,97 & 74 & 3 & 93 \\
1967 & 6.405 & 5,94 & 6.492 & 5,99 & 76 & 14 & 125 \\
\hline
\end{tabular}

Fonte: CBIC (vários anos), utilizando dados do Sindicato Nacional da Indústria de Cimento SNIC

Mesmo nos anos mais difíceis para a indústria de transformação, 1965 e 1967, o setor apresentou taxas positivas na produção e nas vendas. Esse comportamento, como visto anteriormente, se assemelha ao ocorrido na indústria automobilística. No entanto, enquanto o setor de automóveis teve uma atenção especial e em alguns momentos o governo colocou em prática políticas diretas de auxílio ao setor, a indústria de cimento se beneficiou indiretamente de políticas e programas 
do governo para outros setores. A partir de 1966, a demanda por cimento ganhou novo impulso, uma vez que foi colocada em prática uma política habitacional de grande magnitude. O governo Castello Branco criou o Sistema Financeiro Habitacional (SFH), que era formado pelo Banco Nacional da Habitação, pela Caixa Econômica Federal (CEF) e pelas caixas econômicas dos estados. Esse aparato institucional e financeiro voltado para a habitação foi criado pelos militares com o intuito de organizar e efetivar políticas que combatessem a crise de moradia pela qual o país passava. A participação do $\mathrm{BNH}$ no consumo de cimento teve grande importância. No ano de 1967, o BNH foi responsável por 9,3\% do consumo de cimento no país, conforme dados da Revista Conjuntura Econômica (1970). A participação do programa habitacional no consumo de cimento vai crescendo com o passar do tempo e, no ano de 1968, após o Paeg, esse porcentual atinge 13,3\%.

Em todos os anos do período, 1964-1967, a produção e as vendas apresentaram relativa semelhança em seus comportamentos. É importante notar, como evidenciado na Tabela 14, que, em todos os anos, o consumo superou a produção nacional, ainda que por valores reduzidos. O atendimento da demanda no mercado de cimento foi, portanto, complementado com a importação do produto (REVISTA CONJUNTURA ECONÔMICA, 1970).

Em 1964, superando o bom resultado positivo de $5 \%$ da indústria de transformação, a indústria do cimento alcança um crescimento de 7,61\%. No ano seguinte, 1965, as dificuldades aparecem para todos os setores, com a indústria de transformação regredindo 4,7\%. A indústria do cimento desacelerou seu ritmo, apresentando uma variação positiva de $0,73 \%$ no ano. Em 1966, o conjunto dos setores da indústria de transformação cresceu 11,6\% e o ritmo da indústria de cimento voltou a apresentar uma taxa significativa $(7,5 \%)$.

No ano de 1967, a taxa de crescimento da indústria de transformação apresenta uma forte desaceleração: passa de um crescimento de 11,7\%, em 1966, para $2,2 \%$, em 1967. A indústria do cimento apresenta, por sua vez, também uma desaceleração, mas de menor magnitude, passando de 7,5\%, em 1966, para 5,94\%, em 1967 - essa taxa pode ser considerada significativa em vista do agregado da indústria de transformação daquele ano.

\section{Considerações Finais}

O Paeg, a par de sua contribuição inequívoca no tocante às reformas estruturais (tributária, financeira e do setor externo), constituiu-se em uma das poucas experiências bem-sucedidas de estabilização econômica da história econômica brasileira. Tal sucesso em deter e reverter a espiral inflacionária no início dos anos 1960 deve-se, sobretudo, à política salarial fortemente restritiva implementada entre 1965 e 1967. Já as políticas monetária e creditícia evidenciaram-se como ins- 
trumentos muito mais maleáveis por parte do governo, ora com apertos, ora com expansões na moeda e no crédito, expressando, por um lado, um dos principais objetivos do Paeg - a redução da inflação - e, por outro lado, certa preocupação com o crescimento econômico. Como as políticas monetárias e de crédito eram instrumentos para a política anti-inflacionária e, ao mesmo tempo, uma das poucas saídas para manejar e induzir a atividade econômica, já que a política salarial seria restritiva durante todo o período, a maneira como se expressaram foi muito mais errática, com efeitos, portanto, muito mais questionáveis sobre a efetividade da política anti-inflacionária e bem mais contundentes sobre o nível de atividade econômica. No caso da política fiscal há, por um lado, inequívoca redução do déficit fiscal durante o Paeg, mas compensada, ao menos em parte, pelo maior aporte de recursos aos bancos públicos.

Conforme este artigo tentou evidenciar, os impactos das oscilações da política monetária e de crédito sobre o nível de atividade econômica, particularmente sobre o setor industrial e quando considerada uma defasagem de seis meses a um ano, revelaram-se expressivos. O exame mais minucioso da repercussão dessas políticas sobre alguns setores industriais patenteia alguns resultados importantes.

Nos setores analisados de forma mais detalhada, pôde-se observar que o setor siderúrgico foi o que se mostrou mais sensível à inconstância dessas políticas, apresentando retração em 1965, expansão em 1966 e pequena retração em 1967. Por sua vez, o setor automobilístico não apresentou retração entre 1964 e 1967, e há indícios de que esse cenário seja explicado pela atenção especial oferecida pelo governo que estimulou e facilitou a tomada de empréstimos para financiamento de automóveis, a despeito da política anti-inflacionária em vigor. O setor passou por forte desaceleração em 1965 e 1967 e forte crescimento em 1966. Por fim, similarmente, o setor de cimentos não sofreu retração no período analisado, recebendo estímulos indiretos, principalmente a partir de 1966 com a política habitacional do $\mathrm{BNH}$, e destoando da maioria dos setores dessa indústria ao apresentar uma taxa de crescimento de 5,94\% no ano 1967.

Os resultados, em geral positivos da indústria de transformação, mostram que não houve contração de demanda nos setores analisados. Ainda auxiliam a fortalecer o argumento, mencionado no início do trabalho, de que a estabilização lograda pelo Paeg não se deu majoritariamente em função de políticas de contenção de demanda, mas sim, principalmente, em função de fenômenos ligados aos custos de produção e à distribuição da renda, consubstanciados na política salarial. 


\section{Referências}

BANCO DO BRASIL. Relatório 1967. Brasília, DF: [s. n.], 1968.

BASTIAN, E. F. O PAEG e o Plano Trienal: uma análise comparativa de suas políticas de estabilização de curto prazo. Estudos Econômicos, v. 43, n. 1, p. 139-166, 2013.

BIELSCHOWSKY, R. Pensamento econômico brasileiro: o ciclo ideológico do desenvolvimentismo 1930-1964. 3 ed. Rio de Janeiro: Contraponto, 1996. p. 39-40.

CAMPOS, R. O. A lanterna na popa. Rio de Janeiro: Topbooks, 1994.

CBIC - Câmara Brasileira da Indústria da Construção. Banco de dados CBIC. Disponível em: http://www.cbicdados.com.br/menu/materiais-de-construcao/cimento Acesso em: 15 mar. 2018.

FIGUEIREDO, A. C. Democracia ou reformas? Alternativas democráticas à crise política: 1961-1964. São Paulo: Paz e Terra, 1993.

IBGE - Instituto Brasileiro de Geografia e Estatística. Anuário estatístico do Brasil. Rio de Janeiro: IBGE, 1968. v. 29, p. 175. Disponível em: https://biblioteca.ibge.gov.br/index.php/ biblioteca-catalogo?view=detalhesGid=720. Acesso em: 20 dez. 2017.

IBGE - Instituto Brasileiro de Geografia e Estatística. Anuário estatístico do Brasil. Rio de Janeiro: IBGE, 1969. v. 30. Disponível em: https://biblioteca.ibge.gov.br/index.php/bibliotecacatalogo?view=detalhesEid=720. Acesso em: 20 dez. 2017.

IBGE - Instituto Brasileiro de Geografia e Estatística. Estatísticas do século XX. Disponível em: https://seculoxx.ibge.gov.br/economicas/contas-nacionais Acesso em: 15 mar. 2018

IPEADATA. IPEADATA. Disponível em: http://www.ipeadata.gov.br/Default.aspx Acesso em: 01 nov. 2017.

MARTONE, C. L. Análise do plano de ação econômica do governo (PAEG) (1964-1966). In: MINDLIN, B. (org.). Planejamento no Brasil. 4 ed. São Paulo: Perspectiva, 1984. p. 85.

MINISTÉRIO DO PLANEJAMENTO E COORDENAÇÃO ECONÔMICA. Programa de ação econômica do governo (PAEG) (1964-1966). Documentos EPEA, n. 1, p. 15, 1964.

RESENDE, A. L. A política brasileira de estabilização: 1963/1968. Pesquisa e Planejamento Econômico, v. 12, n. 3, p. 757-806, 1982. Disponível em: http://ppe.ipea.gov.br/index.php/ ppe/article/viewFile/395/336. Acesso em: 30 jun. 2017.

RESENDE, A. L. Estabilização e reforma: 1964-1967. In: ABREU, M. P. (org.). A ordem do progresso: cem anos de política econômica republicana 1889-1989. Rio de Janeiro: Campus, 1989. p. 219.

REVISTA CONJUNTURA ECONÔMICA. Rio de Janeiro: FGV, v. 19, n. 2, 1965. Disponível em: http://bibliotecadigital.fgv.br/ojs/index.php/rce/issue/view/3750 Acesso em: 20 dez. 2017. 
REVISTA CONJUNTURA ECONÔMICA. Rio de Janeiro: FGV, v. 20, n. 2, 1966. Disponível em: http://bibliotecadigital.fgv.br/ojs/index.php/rce/issue/view/3774 Acesso em: 20 dez. 2017.

REVISTA CONJUNTURA ECONÔMICA. Rio de Janeiro: FGV, v. 21, n. 2, 1967. Disponível em: http://bibliotecadigital.fgv.br/ojs/index.php/rce/issue/view/3777 Acesso em: 20 dez. 2017.

REVISTA CONJUNTURA ECONÔMICA. Rio de Janeiro: FGV, v. 23, n. 2, p. 50-55, 1969. Disponível em: http://bibliotecadigital.fgv.br/ojs/index.php/rce/issue/view/3830 Acesso em: 20 dez. 2017.

REVISTA CONJUNTURA ECONÔMICA. Rio de Janeiro: FGV, v. 24, n. 7, 1970. Disponível em: http://bibliotecadigital.fgv.br/ojs/index.php/rce/issue/view/3857 Acesso em: 20 dez. 2017.

REVISTA CONJUNTURA ECONÔMICA. Rio de Janeiro: FGV, v. 25, n. 5, 1971. Disponível em: http://bibliotecadigital.fgv.br/ojs/index.php/rce/issue/view/3866. Acesso em: 20 dez. 2017.

SIMONSEN, M. H. A política anti-inflacionária. In: SIMONSEN, M. H.; CAMPOS, R. O. A nova economia brasileira. Rio de Janeiro: Biblioteca do Exército: José Olympio, 1979a. p. 83-108.

SIMONSEN, M. H. A imaginação reformista. In: SIMONSEN, M. H.; CAMPOS, R. O. A nova economia brasileira. Rio de Janeiro: Biblioteca do Exército: José Olympio, 1979b. p. 132.

SOUZA, L. D. W. Inflação de custos e inflação de demanda: uma discussão acerca da natureza das causas da inflação. Leituras de Economia Política - UNICAMP, v. 9, p. 19-39, 2001.

TAVARES, M. C. et al. O BNDE no governo Castelo Branco: o desenvolvimento liberal. In: TAVARES, M. C. et al. Memórias do desenvolvimento. Rio de Janeiro: Centro Internacional Celso Furtado de Políticas para o Desenvolvimento, 2010. n. 4, p. 123-129.

VASCONCELLOS, M. A. S.; GREMAUD, A. P.; TONETO JÚNIOR, R. Economia brasileira contemporânea. São Paulo: Atlas, 1999. p. 247-250.

\section{Autor correspondente:}

Marcelo Álvares de Lima Depieri

E-mail: cellodepieri@gmail.com

Recebido em: 06/10/2018.

Aceito em: 24/08/2019.

\section{(cc) BY}

